Creative Commons User License: CC BY-NC-ND

Abstracted by: EBSCOhost, Electronic Journals Service (EJS),

Google Scholar, Journal Seek, Scientific Commons,

Food and Agricultural Organization (FAO), CABI and Scopus
Journal of Agricultural Extension

Vol. 23 (1) January, 2019

ISSN(e): 24086851; ISSN(Print); 1119944X

http://journal.aesonnigeria.org

http://www.ajol.info/index.php/iae

Email: editorinchief@aesonnigeria.org

\title{
Comparison of two Agricultural Irrigation Schemes in Eastern Cape, South Africa.
}

https://dx.doi.org/10.4314/jae.v23i1.16

\section{Agholor, Isaac A.}

School of Agriculture, Agricultural Extension and Rural Resource Management,

Faculty of Agriculture and Natural Sciences,

University of Mpumalanga. Private Bag X11283.

Nelspruit, 1200. South Africa.

Email: Isaac.agholor@ump.ac.za Phone: +27130020131

\section{Abstract}

The study compared two smallholder agricultural irrigation schemes in Eastern Cape, South Africa. Random selection was adopted and a total of 120 households were chosen from the two study sites. The descriptive statistics and logistic regression were used for data interpretation and analysis. In Zanyokwe and Shiloh schemes: findings reveal that farm experience $(\beta=-.077)$ and $(\beta=-118)$, size of farmland $(\beta=9.970)$ and $(\beta .013)$, permission to occupy $(\beta=.970)$ and $(\beta-439)$, farm resources $(\beta=-1.430)$ and $(\beta=1.993)$, water for irrigation $(\beta=1.299)$ and $\beta=2.197)$, access to market information $(\beta=.768)$ and $\beta=-807)$, and production output $(\beta=-1.390)$ and $\beta=-2.330)$ were significant variables influencing the choice to continue farming on both schemes. The major constraints of beneficiaries were low farm income, inadequate land size, and inadequate farm assets. The study concluded that motivation and involvement of farmers in policy decision making remains critical for success. It is therefore, recommended that training to prepare farmers with multiple skills in sustainable agriculture is paramount.

Keywords: Irrigation schemes, Characteristics, Constraints, Smallholder farmers

\section{Introduction}

In Sub-Saharan Africa, less than 2\% renewable water resources are in use. Agricultural activities in the region are almost completely rain-fed with irrigation presently gaining acceptance and playing a distinct role. However, only about $4 \%$ of the regions entire cultivated area is put under irrigation in comparison to $37 \%$ in Asia, and $14 \%$ in Latin America (Mango, Makate, Tamene, Mponela, and Ndengu, 2018). Increased use of the region's water resources would considerably enhance staple food production and high-value export crops. Smallholder irrigation is an important device in assisting farmers to transit from subsistence agricultural practice to commercial farming. Nevertheless, there are many challenges still facing water resource use in agriculture. These include socio-economic, political, climatic, design aspects, inadequate farmers' participation and lack of planning and management (Jonah, and Dawda, 2014).

The primary aim for the establishment of smallholder irrigation schemes in Sub-Saharan Africa was to provide access to irrigated land and enhance food productivity amongst rural livelihoods (Aquastat, 2015). In a study by the New Partnership for African Development (NEPAD, 2013) on food insecurity, it was concluded that smallholder irrigation increases crop production and also encouraged more agro-industries for processing farm output. The study further asserted that there were increased employment prospects and purchasing power of the people which implies that individuals were able to meet their household needs and thus enhanced food security. 
Creative Commons User License: CC BY-NC-ND

Abstracted by: EBSCOhost, Electronic Journals Service (EJS),

Google Scholar, Journal Seek, Scientific Commons,

Food and Agricultural Organization (FAO), CABI and Scopus
Journal of Agricultural Extension

Vol. 23 (1) January, 2019

ISSN(e): 24086851; ISSN(Print); 1119944X

http://journal.aesonnigeria.org

http://www.ajol.info/index.php/iae

Email: editorinchief@aesonnigeria.org

http://eoi.citefactor.org/10.11226/v23i1

Smallholder irrigators in South Africa are divided into four major groups: farmers with plot in the scheme; autonomous irrigation farmers; communal horticulturists and home gardeners. The majority of smallholder farmers in the irrigation schemes have small plots of land with majority of them farming at a subsistence level (Agholor, 2014).) In 2004, there were about 287 Smallholder Irrigation Schemes (SIS) with approximately 31,000 plot holders as compared to about 1.2million hectare irrigated land in use for commercial agriculture by 28,350 farmers in South Africa. Smallholder irrigation schemes are real assets used to increase the livelihood of smallholder farmers. In sum, the recorded number of smallholder irrigation schemes in 2010 was 302, and it covers a total area of 47,667 hectares with as many as 34,158 plot-holder population (Van Averbeke, 2012).

The benefits of participating in irrigation practices has increased income and better purchasing power of the farmers exemplified by traders' patronage of buying farm produce from irrigation schemes. The development of irrigation schemes in the former homelands of South Africa was to assuage poverty amongst households (Sinyolo, 2013). In these areas (homelands), irrigated agriculture potentially contributed meaningfully to food security, increased income of participating farmers (Agholor, 2013), and employment creation via primary and secondary production activities. While acknowledging the critical importance of smallholder irrigation, the Water Research Commission (WRC), South Africa extended the water resources to accommodate most farming communities (Van Averbeke, 2012). Investment in smallholder irrigation development has a positive effect on rural income, local food supplies and food security of households.

Research on smallholder irrigation scheme in South Africa, however, elucidate that the primary development aims and objectives of establishing Smallholder Irrigation Scheme (SIS) has not been fully realised (Fanadzo, 2012). The poor performance of many SIS has been largely attributed to the problem of low yield exacerbated by poor farming practices which is obvious in most schemes in South Africa. In most smallholder schemes, production records show that maize yield has been less than 3tons/hectare. Low yield has been associated with insufficient technical know-how in crop production among plot holders. The study carried out by Fanadoz, 2012) asserted there were considerable differences between production output achieved by farmers in the scheme and output achieved during on-farm trials using good management practices in Zanyokwe irrigation scheme. Despite the facts that on-farm trial plots are usually smaller and easier to manage than the large field crops. Fanadzo (2012) posited that lack of farm management principles was the main factor hindering crop productivity at Zanyokwe scheme. Smallholder farmers over the years have experienced several challenges in getting access to the markets. The problem of market access was not too pronounced in the era of marketing boards which was in operation from 1940 to 1990 (Van Schalkwyk, Groenewald, Fraser, Obi, Van Tilburg, 2012). The then marketing board were mandated to provide farm inputs, farm services, credits and output market services involving collection of harvest, quality assessment and buying of produce. In most developing countries, marketing boards were dissolved in the 1980s and 1990s mainly because their activities were discovered to be economically unviable and unsustainable following a huge load on the national budget (Van Tilburg, 2012). Following the dissolution, smallholder farmers were unexpectedly deprived of full support services such as the provision of farm inputs (seeds and fertiliser), ploughing of land, extension and credit services, and market services involving the collection of harvest produce, assessment 
Creative Commons User License: CC BY-NC-ND

Abstracted by: EBSCOhost, Electronic Journals Service (EJS),

Google Scholar, Journal Seek, Scientific Commons,

Food and Agricultural Organization (FAO), CABI and Scopus
Journal of Agricultural Extension

Vol. 23 (1) January, 2019

ISSN(e): 24086851; ISSN(Print); 1119944X

http://journal.aesonnigeria.org

http://www.ajol.info/index.php/iae

Email: editorinchief@aesonnigeria.org

http://eoi.citefactor.org/10.11226/v23i1

of quality and purchases of farm products which were hitherto provided by marketing boards (Van Schalkwyk et al., 2012). This situation caused a serious problem amongst smallholders and emerging farmers seeking access to markets while they lack adequate experience to function in a competitive free market economy. In the former homelands of South Africa, smallholders and emerging farmers were deprived of considerable support.

Institutional problems influence the routine maintenance of irrigation infrastructure and water distribution (Van Averbeke, 2012). Lack of maintenance of irrigation infrastructure reduces water delivery and thus poses a menace to the sustenance of irrigated agriculture in South Africa (Makombe, and Kanjere, 2014). Some studies that were carried out by researchers in South Africa observed that tenure restriction negatively impacts and disallowed land-exchange among farmers in most schemes and several studies revealed that men were the main plot holders in the various schemes whilst women were engaged in the actual farming activities. Also the tenure system that is operational in most schemes prohibited farmers from using their plots or land holding as collateral for obtaining loans from banks or any registered financial service provider (Agholor, 2014). The Green Paper on land reform gave clarity on the issue of land tenure in smallholder schemes and noted that the existing tenure system had the highest negative impact when compared to other factors affecting irrigation agriculture (Erlank 2014). In South Africa, the land tenure arrangement is not very distinct mainly because most of the legislation on land tenure system in the smallholder irrigation schemes had been repealed.

Nevertheless, plot holders in most of the scheme still feel confident and secured about their full tenure rights, such as who owns the plots of land but are less confident on renting the land because initially it was forbidden to rent out plots of land (Van Averbeke, 2012). On the other hand, plot holders are also not secured in renting land, because there are no legal protections in place on owners claiming back their plots before the lease agreement lapses. In the assessment of most smallholder irrigation scheme, inadequate support services have been identified as a recurrent issue (Chitsa, 2014). Besides, farmers have not acquired the required level of skill and competence to ideally perform to expectation. However, the need for support services is general although it may vary amongst schemes. Till date, higher institutions assigned to train extension officers; research institutes in charge of technological improvement of smallholder schemes, and public extension mandated for farmers' guidance and support services have performed grossly below expectation (Van Averbeke, 2012).

It is therefore, imperative to comparatively investigate the two notable Smallholder Irrigation Schemes (Shiloh and Zanyokwe) in Eastern Cape, South Africa. The study objectives were as follows:

- investigate the socio-economic profile of farmers in Zanyokwe and Shiloh smallholder irrigation schemes;

- examine the critical factors for choice to remain in the scheme; and

- identify major constraints of smallholder farmers in Zanyokwe and Shiloh irrigation schemes

\section{Methodology}


Creative Commons User License: CC BY-NC-ND

Abstracted by: EBSCOhost, Electronic Journals Service (EJS),

Google Scholar, Journal Seek, Scientific Commons,

Food and Agricultural Organization (FAO), CABI and Scopus
Journal of Agricultural Extension

Vol. 23 (1) January, 2019

ISSN(e): 24086851; ISSN(Print); 1119944X

http://journal.aesonnigeria.org

http://www.ajol.info/index.php/iae

Email: editorinchief@aesonnigeria.org

http://eoi.citefactor.org/10.11226/v23i1

Eastern Cape is located on the South-Eastern seaboard of South Africa. The Province of the Eastern Cape is the second largest of the nine Provinces in terms of surface area, comprising $170600 \mathrm{~km}$ Square, which represents about $14.0 \%$ of the country's total land mass (ECSECC, 2013). Zanyokwe Smallholder Irrigation Scheme is located in the Middle drift area of Amathole district of Eastern Cape, South Africa. It is about $30 \mathrm{~km}$ from King Williams Town and about $20 \mathrm{~km}$ inland on gravel road. The scheme is shared among six villages. The Zanyokwe smallholder irrigation scheme covers approximately 635 hectares of which 434 hectares make up the main Zanyokwe and the rest include Kamma-Furrow.

The Shiloh smallholder irrigation scheme is located in Lukhanji Local Municipality which is situated within the Chris Hani District of the Eastern Cape Province. The scheme is located on the R67 road to Fort Beautfort, about one kilometre from Whittlesea. It is also $40 \mathrm{~km}$ from Queenstown and $102 \mathrm{~km}$ from Fort Beautfort on both sides of the tar road. The total area of the scheme is 455hactare (Lukhanji IDP 2013).

The two irrigation schemes (Zanyokwe and Shiloh) in Eastern Cape Province were used for the comparative study. The justification for selecting these two irrigation schemes were reposed on the popularity and size of the two schemes in the Province. In addition, the priority in funding of the two schemes by the Provincial government calls for investigation of farmers', profile, constraints and willingness to stay-on with the schemes for livelihood.

The individual farm household was considered as the unit of analysis in this study. The sample size for each study site was determined using 5\% margin of error with $95 \%$ confidence interval, and 60 households as determinate population. Based on this set values, a sample size of 60 households were realised. However, for the purpose of this study, 120 households were chosen as the samples size. Sixty households in each study sites were therefore, considered adequate to balance required level of reliability and cost. The data collection procedure involved the use of structured and semi-structured questionnaires, interviews, personal observation and some field measurement. However, in order to ensure proper investigation, focus group discussion was also carried out.

The data were analysed using mean, standard deviation, and IBM-SPSS Statistics software was used to analyse quantitative data obtained from the sample households. The qualitative data were compared and carefully examined for clarity and relevance. The choice of households to remain in the scheme were quantified using the mean, standard deviation and regression analysis described below:

$Y=\beta_{0}+\beta_{1} X_{1}+\beta_{2} X_{2}+$ $+\beta_{11} X_{11}+\mu$

Where:

$\mathrm{Y}=$ Choice to remain in Smallholder Irrigation scheme

$\mathrm{X}_{1}-\mathrm{X}_{11}=$ independent variables demarcated as:

$\mathrm{X}_{1}=$ Gender (Male $=1$, Female $=2$ )

$\mathrm{X}_{2}=$ Age (years)

$\mathrm{X}_{3}=$ Level of education (No school $=1$, Primary school $=2$, Secondary $=3$, Tertiary $=4$ ) 
Creative Commons User License: CC BY-NC-ND

Abstracted by: EBSCOhost, Electronic Journals Service (EJS),

Google Scholar, Journal Seek, Scientific Commons,

Food and Agricultural Organization (FAO), CABI and Scopus

http://eoi.citefactor.org/10.11226/v23i1
Journal of Agricultural Extension

Vol. 23 (1) January, 2019

ISSN(e): 24086851; ISSN(Print); 1119944X

http://journal.aesonnigeria.org

http://www.ajol.info/index.php/iae

Email: editorinchief@aesonnigeria.org

$$
\begin{aligned}
& X_{4}=\text { Farm experience (years) } \\
& X_{5}=\text { Size of farm land (number) } \\
& X_{6}=\text { Distance from farm to nearest access road (number in km) } \\
& X_{7}=\text { Permission to Occupy-PTO (No, PTO }=1 \text {, Yes, PTO =2) } \\
& X_{8}=\text { Sufficient water for Irrigation (Difficult }=1 \text {, Fair }=2 \text {, Good = 3) } \\
& X_{9}=\text { Farming Resources (Poor }=1 \text {, Fair }=2 \text {, Good }=3 \text { ) } \\
& X_{10}=\text { Access to Extension services (yes }=1 \text {, No }=2 \text { ) } \\
& \left.X_{11}=\text { Access to market information (yes }=1 \text {, No }=2\right) \\
& \left.X_{12}=\text { Production output/Yield (unstable }=1 \text {, stable }=2\right) \\
& \beta_{0}=\text { constant } \\
& B_{1} \text { - } \beta_{12}=\text { standardized partial regression coefficients } \\
& \mu=\text { error term }
\end{aligned}
$$

\section{Results and Discussion}

Table 1 illustrates the age of the smallholder schemes beneficiaries in Shiloh and Zanyokwe. Their ages ranged from 44 to 71 years with only $1.7 \%$ of the population aged 44years old. The average age of respondents was $55.7 \%$. The result on the level of education reveals that there were more farmers with junior school education in the Shiloh and Zanyokwe schemes. About $17 \%$ of farmers in Shiloh had high school education and $21.7 \%$ in Zanyokwe. The percentage of farmers who had no formal schooling in Shiloh was $21.7 \%$, while in Zanyokwe it was $15.0 \%$ (Table 1). The percentages of farmers with a tertiary education in Shiloh was $5.0 \%$ and $3.3 \%$ in Zanyokwe. Farm experience shows $1.7 \%$ in Shiloh with a minimum farm experience of five years. In Zanyokwe, $2.5 \%$ of the respondents had five years' farm experience (Table 1). In Shiloh, $4.2 \%$ of the respondents had 10 years' farm experience, while in Zanyokwe it was 3.3\%. The lengthiest farming experience recorded was 20 years with $0.8 \%$ of farmers on both schemes. Nevertheless, the majority of respondents had farm experience ranging from nine years to 17 years on the average. In Shiloh, $45.8 \%$ of the beneficiaries were unemployed while in Zanyokwe $47.5 \%$ were unemployed. However, in Shiloh $4.1 \%$ of the respondents engaged in off-farm activities while $2.5 \%$ also involved in off-farm activities in Zanyokwe (Table 1). However, off-farm activities such as running Spaza shops, hawking, and engaging in menial jobs thrive well in the two study areas. 
Creative Commons User License: CC BY-NC-ND

Abstracted by: EBSCOhost, Electronic Journals Service (EJS),

Google Scholar, Journal Seek, Scientific Commons,

Food and Agricultural Organization (FAO), CABI and Scopus

http://eoi.citefactor.org/10.11226/v23i1
Journal of Agricultural Extension

Vol. 23 (1) January, 2019

ISSN(e): 24086851; ISSN(Print); 1119944X

http://journal.aesonnigeria.org

http://www.ajol.info/index.php/iae

Email: editorinchief@aesonnigeria.org

Table 1: Socio-economic characteristics of household head in the study area

\begin{tabular}{lccc}
\hline $\begin{array}{l}\text { Irrigation } \\
\text { scheme }\end{array}$ & $\begin{array}{c}\text { Shiloh } \\
(n=60)\end{array}$ & \multicolumn{3}{c}{ Zanyokwe } \\
$\begin{array}{l}\text { Household } \\
\text { characteristics }\end{array}$ & Number & $\%$ & $\begin{array}{l}(n=60) \\
\text { Number }\end{array}$
\end{tabular}

\section{Gender:}

Male

Female

Total

Average age:

Marital status:

Married

Single

Widow

Widower

Divorcee

Total

\section{Education}

level:

No school

Primary school Junior school

High school

Tertiary

Total

$\begin{array}{lr}26 & 43.3 \\ 17 & 28.3 \\ 9 & 15.0 \\ 2 & 3.3 \\ 6 & 10.0 \\ 60 & 100\end{array}$

100

\section{Employment \\ status:}

Yes

No

Total

60

\section{Household characteristics}

The characteristics of household heads who have decided to remain in the scheme and households who have decided otherwise for both Shiloh and Zanyokwe are shown in Tables 2 and 3 respectively. The data show positive characteristic differences between household head who are satisfied and have decided to continue farming in the scheme and households who wish to abandon the scheme. In the main, households who do not wish to remain in both Shiloh and Zanyokwe were older than those households that wished to continue. The level of education was a little higher amongst households that wished to continue than 
Creative Commons User License: CC BY-NC-ND

Abstracted by: EBSCOhost, Electronic Journals Service (EJS),

Google Scholar, Journal Seek, Scientific Commons,

Food and Agricultural Organization (FAO), CABI and Scopus
Journal of Agricultural Extension

Vol. 23 (1) January, 2019

ISSN(e): 24086851; ISSN(Print); 1119944X

http://journal.aesonnigeria.org

http://www.ajol.info/index.php/iae

Email: editorinchief@aesonnigeria.org

http://eoi.citefactor.org/10.11226/v23i1

households that do not wished to continue with Shiloh and Zanyokwe smallholder irrigation schemes. Nevertheless, farm size and internal income sources (Spaza shop) were higher among households that do not wished to continue with the scheme. In Shiloh irrigation scheme, most beneficiaries are food plot holders with $49.2 \%$ of farmers accessing less than 1 hectare of land for crop production. In Zanyokwe, $15 \%$ of beneficiaries in the scheme have plot size of $3-6$ hectares with $1.7 \%$ of beneficiaries occupying less than 1 hectare of land. Overall, respondents in both schemes asserted that the total land under irrigation were 450 hectares and 412 hectares respectively. The internal income source for Shiloh were higher among households that do not desire to remain than households that wished to remain in Shiloh scheme (Table 2 and 3). The mean internal source of income for Zanyokwe were: spaza shop 1.22, hawking 1.54, selling liquor 1.23 for beneficiaries who consented to remain in the scheme and spaza shop 1.33, hawking 1.56, selling liquor 1.23 for those who do not. While Shiloh recorded a mean score for spaza shop 1.42, hawking 1.48, selling liquor 1.07 for beneficiaries who agreed to remain in the scheme and spaza 4.0, hawking 1.58, selling liquor .95 for those who do not respectively. The smaller the plot, the more likely beneficiaries were willing to rent out their land and thus result to off-farm activities for income. When plot sizes are too small, it becomes futile to use tractors and other mechanized equipment on fragmented land. Paul and Githinji (2018) reported a positive association between yield and land size of household.

\section{Table 2: Comparison of household characteristics and choice in Shiloh scheme.}

\begin{tabular}{|c|c|c|c|c|}
\hline \multirow[t]{2}{*}{ Variable description (Characteristics) } & \multicolumn{2}{|c|}{$\begin{array}{l}\text { Remain in scheme: Yes } \\
(\mathrm{n}=51)\end{array}$} & \multicolumn{2}{|c|}{$\begin{array}{l}\text { Remain in scheme: } \\
\text { No }(n=9)\end{array}$} \\
\hline & Mean & St. Dev & Mean & St. Dev \\
\hline $\mathrm{Age}^{\star \star \star}$ & 55.75 & 5.809 & 61.30 & 6.730 \\
\hline Marital status & 2.08 & 1.279 & 1.98 & 1.214 \\
\hline Level of education* & 2.60 & 1.153 & 2.38 & 1.091 \\
\hline Farm experience & 12.23 & 3.619 & 12.77 & 3.050 \\
\hline Employment & .10 & 4.37 & .33 & .510 \\
\hline Time spent at home * & 4.37 & 1.057 & 4.63 & .736 \\
\hline \multicolumn{5}{|c|}{ Number of persons living in household, who assist } \\
\hline with farm labour** & 1.33 & .572 & 1.63 & .758 \\
\hline Size of farm land in hectares * & 1.03 & .258 & 1.28 & .490 \\
\hline Location of farm land to the nearest town in $\mathrm{km}$ & 32.28 & 3.189 & 32.13 & 3.022 \\
\hline Distance from farm to nearest access road & .15 & .360 & .35 & .481 \\
\hline Household income: Salary and wages in Rand & 1.30 & .962 & 1.47 & .999 \\
\hline Household income: pension & 1.33 & .896 & 1.23 & .593 \\
\hline Household income : Grants & 1.55 & .723 & 1.68 & .748 \\
\hline Household income: Remittance in kind & 2.32 & .983 & 2.47 & .892 \\
\hline Household income: Remittance in cash & 2.55 & 1.048 & 2.65 & 1.022 \\
\hline Internal sources of household income: Spaza & & & & \\
\hline Internal sources of household income: Shop** & 1.42 & 1.266 & 4.00 & 2.329 \\
\hline \multirow{2}{*}{ Internal sources of household income: Selling liquor } & 1.48 & 1.000 & 1.58 & .966 \\
\hline & 1.07 & .362 & .95 & .502 \\
\hline
\end{tabular}

*** Very Important, ${ }^{* *}$ Important, * moderately important

Though the differences were not significant, households who wished to continue in Zanyokwe had higher land sizes than households who do not wish to remain. Also in 
Creative Commons User License: CC BY-NC-ND

Abstracted by: EBSCOhost, Electronic Journals Service (EJS),

Google Scholar, Journal Seek, Scientific Commons,

Food and Agricultural Organization (FAO), CABI and Scopus

http://eoi.citefactor.org/10.11226/v23i1
Journal of Agricultural Extension

Vol. 23 (1) January, 2019

ISSN(e): 24086851; ISSN(Print); 1119944X

http://journal.aesonnigeria.org

http://www.ajol.info/index.php/iae

Email: editorinchief@aesonnigeria.org

Zanyokwe, the proportions of households that assist with farm labour were slightly higher among households that do not wish to remain with the scheme than households that wish to remain.

Table 3: Comparison of household characteristics and choice in Zanyokwe scheme.

\begin{tabular}{|c|c|c|c|c|}
\hline \multirow[t]{2}{*}{ Variable description (Characteristics) } & \multicolumn{2}{|c|}{$\begin{array}{l}\text { Continue with } \\
\text { scheme: Yes } \\
(n=55)\end{array}$} & \multicolumn{2}{|c|}{$\begin{array}{l}\text { Continue with } \\
\text { scheme: No }(n=5)\end{array}$} \\
\hline & Mean & St. Dev & Mean & St. Dev \\
\hline $\mathrm{Age}^{\star \star \star}$ & 59.12 & 6.471 & 61.38 & 6.219 \\
\hline Marital status & 2.22 & 1.451 & 1.73 & 1.219 \\
\hline Level of education * & 2.75 & 1.068 & 2.53 & 1.033 \\
\hline Farm experience & 12.05 & 3.624 & 12.45 & 3.223 \\
\hline Employment & 1.95 & .220 & .17 & .376 \\
\hline Time spent at home ** & 4.22 & .993 & 3.63 & 1.207 \\
\hline Number of persons living with household & & & & \\
\hline that assist with farm labour* & 2.08 & .787 & 2.68 & .869 \\
\hline Size of farm land in hectares** & 3.17 & 1.11 & 2.40 & 1.265 \\
\hline $\begin{array}{l}\text { Location of farm land to the nearest town in } \\
\mathrm{km}\end{array}$ & 43.45 & 4.3000 & 43.23 & 4.236 \\
\hline Distance from farm to nearest access road & .78 & .415 & .87 & .343 \\
\hline $\begin{array}{l}\text { Household income: Salary and wages in } \\
\text { Rand }\end{array}$ & 2.40 & .694 & 2.70 & .869 \\
\hline Household income: pension & 1.45 & 1.064 & 1.52 & 1.066 \\
\hline Household income: Grants & 1.73 & .841 & 1.73 & .841 \\
\hline Household income: Remittance in kind & 2.57 & 1.064 & 2.56 & 1.065 \\
\hline $\begin{array}{l}\text { Household income: Remittance in cash } \\
\text { Internal sources of household income: }\end{array}$ & 2.87 & 1.96 & 2.86 & 1.096 \\
\hline Spaza & 1.22 & .958 & 1.33 & 1.003 \\
\hline $\begin{array}{l}\text { Internal sources of household income: } \\
\text { Hawking } \\
\text { Internal sources of household income: }\end{array}$ & 1.54 & 1.185 & 1.56 & 1.185 \\
\hline Selling liquor & 1.23 & 1.031 & 1.23 & 1.031 \\
\hline
\end{tabular}

${ }^{* * *}$ Very Important, ${ }^{* *}$ Important, * moderately important

\section{Factors Influencing Choice to Continue with Zanyokwe and Shiloh Irrigation Schemes.}

Reflecting on the model fit, the Leme show Goodness-of- Fit test statistics was 1.00, while Nagelkerke $\mathrm{R}^{2}$ was computed as a proxy estimate to $\mathrm{R}^{2}$ in OLS regression and this measures the proportion of variation or differences in the response as clarified by the model. The Nagelkerke $\mathrm{R}^{2}$ of $0.398(39.8 \%)$ and $0.608(60.8 \%)$ was obtained for Shiloh and Zanyokwe which mean that more of the variations were explained in Zanyokwe and less in Shiloh as illustrated in tables 4 and 5 with overall predicted percentage of 83.3 and 81.7 for Shiloh and Zanyokwe, respectively. 
Creative Commons User License: CC BY-NC-ND

Abstracted by: EBSCOhost, Electronic Journals Service (EJS),

Google Scholar, Journal Seek, Scientific Commons,

Food and Agricultural Organization (FAO), CABI and Scopus
Journal of Agricultural Extension

Vol. 23 (1) January, 2019

ISSN(e): 24086851; ISSN(Print); 1119944X

http://journal.aesonnigeria.org

http://www.ajol.info/index.php/iae

Email: editorinchief@aesonnigeria.org

http://eoi.citefactor.org/10.11226/v23i1

Seven variables (farm experience, size of farmland, permission to occupy, sufficient water for irrigation, farm asset, access to market information and production output) out of the twelve variables were found to have significant effect in influencing household choice to continue in Shiloh smallholder irrigation scheme, while five variables (gender, age, education, distance from farm to nearest access road and access to extension services) were not significant (Table 4). Of the seven significant variables, four had positive signs (permission to occupy, sufficient water for irrigation, and access to market information); which means that an increase in either of these variables may be associated with an increase in household choice to continue with Shiloh scheme. The other three predictor variables (farm experience, farm asset and product variation) had negative signs; this means an increase in either of these variables may be associated with a decrease of intention to continue.

In contrast, six variables (farm experience, permission to occupy, sufficient water for irrigation, farm asset, access to market information and production output) out of the twelve analysed variables were found to have substantial impact on influencing household decision, while six variables (gender, age, education, size of farm land, road distance and access to extension services) were not significant (Table 5). From the six significant variables, two had positive signs (sufficient water for irrigation and farm asset); which means that an increase in either of these variables may be associated with an increase in household choice to continue farming in Zanyokwe. The other four predictor variables (farm experience, permission to occupy, access to market information and production output) had negative signs; this means an increase in either of these variables may be associated with a decrease in choice making.

\section{Farm experience}

Farm experience of households had significant relationship on both schemes (Shiloh and Zanyokwe) with coefficients of (-.077 and -.118) but negatively related to choice to continue farming. The result indicates that an increase in household farm experience on both schemes will lead to a decrease in the choice to continue farming. In a study by Adekunle, Oladipo, and Busari (2015) found a contradictory result that experienced farmers with managerial skill are more inclined to make better informed choice and are more likely to remain in farming.

\section{Permission to occupy}

The permission to occupy had positive relationship to choice to remain in both schemes with a coefficient of value of .970 and -.439 which indicate that it influences choice to continue participation in the scheme. The findings from both schemes show that the choice of households to continue farming in the schemes increases with an increase in permission to occupy. This result bears similar reference to that of Sihlobo (2015) who found that security of land tenure limits farmers' performance in Eastern Cape.

\section{Access to market information}

The coefficient for access to market information (0.768) was positively significant in Shiloh irrigation scheme. In consonant to this, an increase in access to market information increases the potential for choice to remain in Shiloh scheme. On the contrary, Zanyokwe 
Creative Commons User License: CC BY-NC-ND

Abstracted by: EBSCOhost, Electronic Journals Service (EJS),

Google Scholar, Journal Seek, Scientific Commons,

Food and Agricultural Organization (FAO), CABI and Scopus

http://eoi.citefactor.org/10.11226/v23i1
Journal of Agricultural Extension

Vol. 23 (1) January, 2019

ISSN(e): 24086851; ISSN(Print); 1119944X

http://journal.aesonnigeria.org

http://www.ajol.info/index.php/iae

Email: editorinchief@aesonnigeria.org

recorded a significant but negatively related to access to market information. This result indicates that any increase in access to market information will lead to a decrease in choice to continue farming. This is so because sufficient access to market information may not likely be the only motivating factors for households to continue farming.

\section{Production output}

The production output had a significant relationship on both schemes with $(-1.390$ and 2.330) but negatively influence the choice to continue farming on both schemes respectively. The implication here, is that any increase in production output may not lead to upsurge to continue with the scheme because farmers considers other factors and priorities to finalize decision to either remain in the scheme or abandon the scheme. This result contradicts the findings by Menozzi, Fioravanzi, and Donati (2015), that farmers with higher returns on farming investment were likely to be motivated to continue farming.

Table 4: Factors influencing choice in Shiloh scheme

\begin{tabular}{|c|c|c|c|c|}
\hline Variabies & & Coefifficients & Std. Error & t-vaiuie \\
\hline Gender $\left(X_{1}\right)$ & & -.631 & .632 & .318 \\
\hline Age $\left(X_{2}\right)$ & & -.004 & .054 & .946 \\
\hline $\begin{array}{l}\text { Level of education } \\
\left(\mathrm{X}_{3}\right)\end{array}$ & & -.165 & .274 & .548 \\
\hline Farm experience $\left(X_{4}\right)$ & & -.077 & .089 & $.038^{*}$ \\
\hline Size of farm land $\left(X_{5}\right)$ & & 9.970 & 20096.480 & $.010^{*}$ \\
\hline $\begin{array}{l}\text { Distance from farm to } \\
\text { nearest access road } \\
\left(X_{6}\right)\end{array}$ & & -.53987 & .775 & .487 \\
\hline $\begin{array}{ll}\text { Permission } & \text { to } \\
\text { Occupy-PTO }\left(X_{7}\right) & \end{array}$ & & .970 & .680 & $.015^{*}$ \\
\hline $\begin{array}{l}\text { Sufficient water for } \\
\text { Irrigation }\left(X_{8}\right)\end{array}$ & & 1.299 & 1.096 & $.023^{*}$ \\
\hline Farm Resources $\left(X_{9}\right)$ & & -1.430 & .678 & $.035^{*}$ \\
\hline $\begin{array}{l}\text { Access to Extension } \\
\text { services }\left(X_{10}\right)\end{array}$ & & 1.076 & .720 & .135 \\
\hline $\begin{array}{l}\text { Access to market } \\
\text { information }\left(X_{11}\right)\end{array}$ & & .768 & .668 & $.012^{*}$ \\
\hline $\begin{array}{l}\text { Production output } \\
\left(X_{12}\right)\end{array}$ & & -1.390 & .598 & $.020^{*}$ \\
\hline $\begin{array}{l}-2 \text { Log likelihood } \\
\text { Lagelkerke } \mathrm{B}^{2}\end{array}$ & $43.711^{a}$ & & & \\
\hline $\begin{array}{l}\text { Nagelkerke } \mathrm{R}^{2} \\
\text { Percentage correctly } \\
\text { predicted }\end{array}$ & $\begin{array}{l}.398 \\
84.2\end{array}$ & & & \\
\hline
\end{tabular}


Creative Commons User License: CC BY-NC-ND

Abstracted by: EBSCOhost, Electronic Journals Service (EJS),

Google Scholar, Journal Seek, Scientific Commons,

Food and Agricultural Organization (FAO), CABI and Scopus

http://eoi.citefactor.org/10.11226/v23i1
Journal of Agricultural Extension

Vol. 23 (1) January, 2019

ISSN(e): 24086851; ISSN(Print); 1119944X

http://journal.aesonnigeria.org

http://www.ajol.info/index.php/iae

Email: editorinchief@aesonnigeria.org

Table 5: Factors influencing choice in Zanyokwe

\begin{tabular}{|c|c|c|c|}
\hline Variables & Coefficients & Std. Error & t-value \\
\hline Gender $\left(X_{1}\right)$ & .35 & .613 & .559 \\
\hline Age $\left(X_{2}\right)$ & -.039 & .044 & .371 \\
\hline Level of education $\left(\mathrm{X}_{3}\right)$ & .155 & .263 & .556 \\
\hline Farm experience $\left(X_{4}\right)$ & -.118 & .081 & $.014^{*}$ \\
\hline Size of farm land $\left(X_{5}\right)$ & .013 & .277 & .963 \\
\hline $\begin{array}{l}\text { Distance from farm to nearest } \\
\text { access road }\left(X_{6}\right)\end{array}$ & -2.008 & 1.083 & .064 \\
\hline $\begin{array}{l}\text { Permission to Occupy-PTO } \\
\left(X_{7}\right)\end{array}$ & -.439 & 659 & $.01^{*}$ \\
\hline $\begin{array}{l}\text { Sufficient water for Irrigation } \\
\left(\mathrm{X}_{8}\right)\end{array}$ & 2.197 & .877 & $.012^{*}$ \\
\hline Farm Resources $\left(X_{9}\right)$ & 1.993 & .810 & $.014^{*}$ \\
\hline $\begin{array}{l}\text { Access to Extension services } \\
\left(X_{10}\right)\end{array}$ & 1.026 & .586 & .080 \\
\hline $\begin{array}{ll}\text { Access } & \text { to } \\
\text { information }\left(X_{11}\right) & \text { market }\end{array}$ & -.807 & 645 & $.003^{\star *}$ \\
\hline Production output/yield $\left(X_{12}\right)$ & -2.330 & 699 & $.001^{* *}$ \\
\hline $\begin{array}{l}-2 \text { Log likelihood } \\
\text { Nagelkerke } R^{2} \\
\text { Percentage correctly predicted }\end{array}$ & $\begin{array}{l}41.810^{\mathrm{a}} \\
.608 \\
80.7\end{array}$ & & \\
\hline
\end{tabular}

${ }^{*} \mathrm{P} \leq 0.05$

\section{Size of farmland}

Size of farmland was found to be significant only in Shiloh (9.970) and positively related to decision making of households. This imply that any increase in land size will lead to increase of household choice to continue farming in the scheme. The plausible reason for this result could be that most farmers with small land holding are limited from expansion and profit maximization. Thus as landholding size decreases, farmers become more inclined to participating in off-farm undertakings.

\section{Farm resources}

Farm resource was found to be significant in Shiloh $(-1.430)$ but negatively influence choice to remain in Shiloh irrigation scheme. In contrast, farm resource in Zanyokwe recorded a significant and positive relationship to continue farming. The result explains that any increase in farm resources for households in Shiloh scheme will lead to a decrease in the choice to continue farming. Conversely, any increase in farm resources in Zanyokwe will lead to increase in the choice to continue farming in the scheme. 
Creative Commons User License: CC BY-NC-ND

Abstracted by: EBSCOhost, Electronic Journals Service (EJS),

Google Scholar, Journal Seek, Scientific Commons,

Food and Agricultural Organization (FAO), CABI and Scopus

http://eoi.citefactor.org/10.11226/v23i1
Journal of Agricultural Extension

Vol. 23 (1) January, 2019

ISSN(e): 24086851; ISSN(Print); 1119944X

http://journal.aesonnigeria.org

http://www.ajol.info/index.php/iae

Email: editorinchief@aesonnigeria.org

\section{Sufficient water for irrigation}

Sufficient water for irrigation had a positive relationship with choice to remain in both irrigation schemes with coefficient of 1.299 and 2.197 for Shiloh and Zanyokwe respectively. The result indicates that the choice of household to remain in the scheme increases with enough water for irrigation. In a study by Jonah and Dawda (2014) also revealed that the low performance of crop yield in most irrigation scheme is aggravated by water shortages.

\section{Constraints of Smallholder Farmers in Shiloh and Zanyokwe}

The constraints faced by both schemes beneficiaries are shown in Table 6 .

\section{Inadequate land size}

In Shiloh (88\%) and Zanyokwe (50\%) of plot holders rent out their plot to other farmers on a share cropping basis because of the small sizes of plots allocated to them.(Table 6). In Shiloh, the majority of plot holders were initially involved in plot renting or sharecropping for dividends primarily because the plots allocated to a household were too small for sustenance. Majority of Shiloh scheme beneficiaries favoured the renting of their plots to the owner of the dairy project near the scheme. However, the majority of plot holders in Shiloh, at the time of this study had been reduced to mere land (plot holders) owners whose business was to watch the on-going farming activities at the dairy project site while waiting for annual rental income.

\section{Low farm income}

Low level of farm income on both schemes pose a challenge for the beneficiaries. In Shiloh, $(92 \%)$ and Zanyokwe $(68 \%)$ of respondents agreed that low level of farm income was discouraging. (Table 6). During harvest season, there is usually an increased aggregate output which will definitely increase the market supply of vegetables causing a fall in farm income. All things being equal, the higher the supply the lower the price of a given commodity hence the increased loss of farm revenue (income) in the case of inelastic demand.

\section{Inadequate farm asset and infrastructure}

In Shiloh scheme, $76.6 \%$ of beneficiaries identified inadequate farm asset as a constraint and in Zanyokwe, 59.3\% also were of the view that farm infrastructure hampers their performance on the field. (Table 6). Smallholder farmers' investment decision making in a given period depends on the available resources and access to appropriate irrigation facilities. Household decision to increase the size of their cultivated land or invest on the production of new crops depends on the farm implement or infrastructure at his/her disposal. This result lead credence to the findings by Mvelase (2016) who found that lack of farm infrastructure and inadequate daily maintenance of irrigation infrastructure is the primary cause of low performance that has characterised smallholder irrigation schemes in South Africa.

\section{Poor soil fertility}

On both schemes, the percentage of beneficiaries who identified low soil fertility as constraints were $72 \%$ and $67 \%$ for Shiloh and Zanyokwe respectively. (Table 6). Most 
Creative Commons User License: CC BY-NC-ND

Abstracted by: EBSCOhost, Electronic Journals Service (EJS),

Google Scholar, Journal Seek, Scientific Commons,

Food and Agricultural Organization (FAO), CABI and Scopus
Journal of Agricultural Extension

Vol. 23 (1) January, 2019

ISSN(e): 24086851; ISSN(Print); 1119944X

http://journal.aesonnigeria.org

http://www.ajol.info/index.php/iae

Email: editorinchief@aesonnigeria.org

http://eoi.citefactor.org/10.11226/v23i1

irrigated land in the scheme were impoverished with low nutrient content leading to low crop yield. The application of chemical fertiliser became an alternative to enhance good crop yield. Infertile soil has an effect on farmers' decision making. Good returns from fertile soil positively influences farmers' decision making especially in the area of increasing the quantity of crops to cultivate. However, the cost of fertilizers also increases production cost. Nevertheless, households that use fertilisers are more likely to have improved investment decision making than non-users.

\section{Inadequate water supply for irrigation}

In Shiloh scheme, $58 \%$ of beneficiaries asserted that inadequate water supply was a challenge, while in Zanyokwe 53\% agreed that water supply was also a problem. (Table 6). In South Africa, irrigated land use for agriculture accounts for as much as $30 \%$ of the total crop production and water consumption via irrigation is the largest compared to other sector. Water availability allows the increased use of agrochemicals like fertilisers which in turn increases the level of yield and improves farm income. Inadequate water limits crop and livestock production (Chukwuone, Chukwuone, and Amaechina, 2018).

\section{Inadequate market information}

In Shiloh (65\%) and Zanyokwe (59\%) schemes, beneficiaries agreed that inadequate market information poses a challenge. (Table 6). When farmers are constrained with information about prices, they may sell their produce at low price and buy when prices are high. The availability of market information influences smallholder farmer's production and investment options. An ideal functioning market normalises access to credits and reduce capital constraints (Shuaibu, Akinola, Akpoko, Damisa, and Yakubu, 2018). Sizeable amount of market information is pertinent to back up agricultural activities and to improve farmers' knowledge and farming efficiency.

\section{Problem of low yield}

The smallholder schemes beneficiaries in Shiloh and Zanyokwe schemes, who agreed that the problem of low yield remains a challenge were $74 \%$ and $69 \%$ respectively. (Table 6 ). The problem of low yield exacerbated by poor farming practices has been obvious in most schemes in South Africa (Sinyolo, 2013). In most smallholder schemes, production records show that maize yield has been less that 3tons/hectare. Study have shown that there were considerable differences between production output achieved by farmers in the scheme and output achieved on-farm trials using good management practices in Zanyokwe irrigation scheme (Van Averbeke, 2013). Despite the facts that on-farm trial plots are usually smaller and easier to manage than the large field crops, the findings of Fanadzo (2012) posited that lack of farm management principles was the main factor hindering crop productivity at Zanyokwe scheme. The perceived farmers' satisfaction and variations in the annual rate of yield coupled with prices offered for agricultural produce occasioned by imperfect markets are expected to make smallholder face low and different price decisions depending on each household equilibrium trading position. Overall, there was low cropping intensity in both Shiloh and Zanyokwe irrigation schemes which resulted in low yield. In Zanyokwe, some of the plot holders were old and could not fully cultivate their irrigated plots of land. Respondents also asserted that late arrival of farm inputs and infrastructural deficiencies exacerbated by inadequate maintenance, contributed to low yields in both schemes. 
Creative Commons User License: CC BY-NC-ND

Abstracted by: EBSCOhost, Electronic Journals Service (EJS),

Google Scholar, Journal Seek, Scientific Commons,

Food and Agricultural Organization (FAO), CABI and Scopus

http://eoi.citefactor.org/10.11226/v23i1
Journal of Agricultural Extension

Vol. 23 (1) January, 2019

ISSN(e): 24086851; ISSN(Print); 1119944X

http://journal.aesonnigeria.org

http://www.ajol.info/index.php/iae

Email: editorinchief@aesonnigeria.org

\section{Table 6: Main constraints of smallholder irrigation scheme beneficiaries}

\begin{tabular}{lll}
\hline Main constraints & $\begin{array}{l}\text { Shiloh } \\
(\%)\end{array}$ & $\begin{array}{l}\text { Zanyokwe } \\
(\%)\end{array}$ \\
\hline Inadequate land size & 88.21 & 76.45 \\
Low farm income & 92.23 & 68.74 \\
Inadequate farm asset and infrastructures & 76.62 & 59.32 \\
Poor Soil fertility & 72.35 & 67.23 \\
Inadequate water supply for Irrigation & 58.42 & 53.81 \\
Inadequate Market information & 65.12 & 59.31 \\
Problem of Low yield & 74.46 & 69.49 \\
\hline
\end{tabular}

${ }^{\star}$ Multiple responses

\section{Conclusion and Recommendations}

Participation and choice to continue with the two government funded smallholder irrigation schemes in Eastern Cape South Africa, were influenced by: size of farmland, farm experience, permission to occupy, farm resources, water for irrigation, access to market information, and production output. Conversely, a number of constraints encountered by the scheme beneficiaries were inadequate land size, low farm income, inadequate farm asset and infrastructures, poor Soil fertility, inadequate water supply for irrigation, inadequate market information and problem of low yield. In spite of these numerous constraints, smallholder irrigation schemes still remain an efficient and sustainable avenue to assuage poverty in South Africa in view of the gifted agro-ecological diversity of the country.

Nonetheless, a variety of initiatives should be put in place to develop environmental policy across a range of sectors. For instance, water policies should be developed with strategies to minimize water tariff and charges since irrigated agriculture requires water. The role of farmers and their participation in effective water use efficiency will assist in bringing about a sustainable smallholder irrigation practice. Training to prepare farmers with skills in sustainable agriculture are paramount and priority must be given to multiple skills development. Capacity development for most community centred organisations that are representing the smallholder farmers should be accorded priority so as to ameliorate some of the constraints of smallholder irrigation scheme beneficiaries. The effect of market and socio-economic conditions on the motivation of farmers must be critically considered. Workable strategies must not be one-size fits all but must be dynamic and sensitive to the felt needs of the local farmers. Motivation and involvement of farmers in decision making are critical components attached to farmers' success in small holder irrigation schemes.

\section{References}

Adekunle, O. A., Oladipo, F. and Busari, I. (2015). Factors affecting farmers' participation in irrigation schemes of the lower niger river basin and rural development Authority, Kwara State, Nigeria. S. Afr. J. Agric. Ext., 43 (2): 42- 49.

Agholor, A.I. (2013). The revitalisation of water resources for sustainable agricultural development in South Africa: A review. Journal of Agricultural Science; 5 (5): 76- 78. 
Creative Commons User License: CC BY-NC-ND

Abstracted by: EBSCOhost, Electronic Journals Service (EJS)

Google Scholar, Journal Seek, Scientific Commons,

Food and Agricultural Organization (FAO), CABI and Scopus

http://eoi.citefactor.org/10.11226/v23i1
Journal of Agricultural Extension

Vol. 23 (1) January, 2019

ISSN(e): 24086851; ISSN(Print); 1119944X

http://journal.aesonnigeria.org

http://www.ajol.info/index.php/iae

Email: editorinchief@aesonnigeria.org

Agholor A.I. (2014). Analysis of Decision Making in Smallholder Irrigation Practice: A Case tudy of Shiloh and Zanyokwe Irrigation schemes in Central Eastern Cape. PhD Thesis (Agricultural Extension), University of Fort Hare, South Africa

Aquastat, (2015). Information System on Water and Agriculture. Food and Agriculture Organisation. Retrieved November 9, 2018. From:

http://www.fao.org/nr/water/aquastat/coutries_regions.

Chitsa, G. (2014). Analysis of Entrepreneurial Behaviour of Smallholder Irrigation Empirical Evidence from Qamata Irrigation Scheme. M.Sc Dissertation (Agricultural Economics), University of Fort Hare, South Africa

Chukwuone, N. A., Chukwuone, C., Amaechina, E. (2018). Sustainable land management practices used by farm households for climate change adaptation in South East Nigeria. Journal of Agricultural Extension, 22(3): 185-189

Eastern Cape Socio Economic Consultative Council (ECSCC), (2013). Retrieved November 9, 2018. From: https://www.ecsecc.org/search.aspx

Erlank, W. (2014). Green Paper on Land Reform: Overview and Challenges. Vol. 17 No 2. Retrieved November 9, 2018. From: http://dx.doi.org/10.4314/pelj.v17i2.01

Fanadzo, M. (2012). Revitalisation of smallholder irrigation schemes for poverty Alleviation and household food security in South Africa: A review. African Journal of Agricultural Research 7 (13): 1956 - 1969.

Integrated Development Plan (IDP) 2013 / 2014. $1^{\text {st }}$ Review: Final Draft. Lukhanji Local Municipality. Retrieved November 9, 2018. From: https://www.ecsecc.org/documentrepository/informationcentre/Final Draft ID P 201 3 2014Lukhanji.pdf

Jonah, A and Dawda, T.K. (2014). Improving the management and use of water resources $f$ or small-scale irrigation farming in the Garu Tempane District of Ghana. Journal of Sustainable Development 7 (6): 214 - 222.

Mango, N., Makate, C., Tamene, L., Mponela, P., and Ndengu, G. (2018). Adoption of small-scale irrigation farming as a climate-smart agriculture practice and its influence on household income in the Chinyanja Triangle, Southern Africa. Land, 7:49:2-3

Menozzi, D., Fioravanzi, M, Donati, M. 2015. Farmer's motivation to adopt sustainable agricultural practices. Bio-based and Applied Economics 4(2): 125-147, 2015.

Mvelase, T.C. (2016). Developing Practical Solutions to Problems and Constraints Faced by Smallholder Irrigation Schemes in South Africa. M.Sc. Thesis (Bio-resources University of KwaZulu-Natal, South Africa.

New Partnership for African Development-NEPAD, (2013). Agriculture Food Security Report. Retrieved November 9, 2018. From: http://www.nepad.org/caadp/publication/2013-agriculture-food-security-report 
Creative Commons User License: CC BY-NC-ND

Abstracted by: EBSCOhost, Electronic Journals Service (EJS)

Google Scholar, Journal Seek, Scientific Commons,

Food and Agricultural Organization (FAO), CABI and Scopus

http://eoi.citefactor.org/10.11226/v23i1

Paul, M. and Gĩthĩnji, M (2018). Small farms, Smaller plots: Productivity in Ethiopia, The Journal of Peasant Studies,
Journal of Agricultural Extension

Vol. 23 (1) January, 2019

ISSN(e): 24086851; ISSN(Print); 1119944X

http://journal.aesonnigeria.org

http://www.ajol.info/index.php/iae

Email: editorinchief@aesonnigeria.org

Fragmentation,

and

Shuaibu, H; Akinola, M.O., Akpoko, J.G., Damisa, M.A. and Yakubu, D.H. (2018). S ocioeconomic factors and profitability of groundnut processing by women in Kano state, Nigeria. Journal of Agricultural Extension. 22(2): 1-10.

Sihlobo, W. (2015). Land Tenure Limits Eastern Cape's Crops. Mail and Guardian, Nov 10, 2018. Page 2. Retrieved November 9, 2018. From:

https://mg.co.za/article/2015-03- 19-land-tenure-limits-eastern-capes-crops

Sinyolo, S. (2013). The Impact of Smallholder Irrigation and Water security on Household Welfare: The case of Tugela Ferry irrigation scheme in KwaZulu- Natal, South Africa. Master Thesis (Agricultural Economics), University of KwaZulu-Natal, Pietermaritzburg, South Africa.

Van Averbeke, W. (2012). Performance of Smallholder Irrigation Schemes in the Vhembe District of South Africa. In: Kumar, M.D. (ed.) Problems, Perspectives and Challenges of Agricultural Water Management. Rijeka, Croatia: In Tech.

Van Averbeke, W. (2013). Improving Plot Holder Livelihood and Scheme Productivityon Smallholder Canal Irrigation Schemes in the Vhembe District of Limpopo Province.

Report No. TT 566/13. Water Research Commission, Pretoria, Republic of South Africa.

Van Tilburg, A, (2012). Strategies to Improve Smallholders' Market Access. In Unlocking Markets to Smallholders (ed.) Van Schalkwyk, H.D., Groenewald, A. J., Fraser, C.G., Obi, A., Van Tilburg, A,. 2012. Lessons from South Africa. Wageningen Academic Publishers, 6700. AE, Wageningen, Netherlands.

Van Schalkwyk, H.D., Groenewald, A. J., Fraser, C.G., Obi, A., Van

Tilburg, A. (2012). Unlocking Markets to Smallholders. Lessons from South Africa.

Wageningen Academic Publishers, 6700. AE, Wageningen, Netherlands.

Van Tilburg, A, (2012). Strategies to Improve Smallholders' Market Access. In Unlocking Markets to Smallholders (ed.) Van Schalkwyk, H.D., Groenewald, A. J., Fraser, C.G., Obi, A., Van Tilburg, A, 2012. Lessons from South Africa. Wageningen, Academic Publishers, 6700. AE, Wageningen, Netherlands. 